\title{
Anomalous responses to stimulation and suppression tests in Cushing's syndrome due to a calcified adrenal adenoma
}

\author{
S. EPSTEIN \\ M.B., M.R.C.P.
}

\author{
E. H. MCLAREN \\ B.Sc., M.B., M.R.C.P. (U.K.)
}

\author{
A. R. Goldin \\ M.B., F.C.P. (S.A.), F.F.R. \\ Endocrine Unit, Department of Medicine and Department of \\ Diagnostic Radiology, Groote Schuur Hospital and University of Cape Town
}

\begin{abstract}
Summary
A case of Cushing's syndrome, due to an adrenal adenoma, which responded to dexamethasone with a rise in plasma urinary steroids is described. Further unusual features were radiologically visible calcification and a response to ACTH stimulation.
\end{abstract}

\section{Introduction}

The differential diagnosis of the various forms of Cushing's syndrome rests mainly on the response of the adrenal glands to stimulation and suppression. Usually Cushing's syndrome due to adrenal hyperplasia is suppressed by dexamethasone in sufficient doses and stimulated by ACTH and metapyrone. Tumours either benign or malignant are usually non-responsive to stimulation or suppression by these agents. Adrenal venography may also help differentiate between tumour or hyperplasia. The results of these findings are important in that they determine the management of the disease. There have been previous reports of anomalous responses to metapyrone and dexamethasone in that tumours also may show suppression or stimulation, i.e. non-autonomy. It is, however, uncommon for any cause for Cushing's syndrome to be stimulated by dexamethasone. We wish to report a patient who had Cushing's syndrome due to a proven adrenocortical adenoma which was not only stimulated by dexamethasone but was also responsive to ACTH stimulation. Another unusual feature was the presence of radiologically visible calcification in the adenoma.

\section{Case report}

In 1970 the patient, a white female then aged 31 years, developed thyrotoxicosis which was treated by subtotal thyroidectomy. She was seen in Groote Schuur Hospital in May 1972 when she gave an 18-month history of increasing weight, facial hirsutes, easy bruising and depression. She also complained of low back pain and generalized weakness.
Her periods had been irregular since the menarche but 3 years previously she had been started on norethisterone which had temporarily regularized them. However, for the past 6 months her periods had once again become irregular in spite of the norethisterone.

On systematic enquiry her only other complaint was of occasional ankle swelling. Her thyroxine had been stopped 4 months previously but she continued to take norethisterone daily throughout her investigation.

On examination the striking clinical feature was a round, full face, plethora and minimal hirsutes. A small buffalo hump, centripetal obesity and occasional pink striae were also evident. The thyroidectomy scar was well healed and the patient was clinically euthyroid. She was slightly hypertensive with a BP of $145 / 90 \mathrm{mmHg}$ but physical examination was otherwise normal.

\section{Methods}

Plasma fluorogenic corticoids were measured by method of Mattingly (1962), urinary steroids were measured by the Zimmermann reaction using the method of Drekter et al. (1952) for the 17 oxosteroids and that of Few (1961) for the 17 oxogenic steroids.

\section{Investigation}

Hb $16.7 \mathrm{~g} / 100 \mathrm{ml}$, WBC $12,500 / \mathrm{mm}^{3}$, differential count: neutrophils $85 \%$, lymphocytes $12 \%$, eosinophils $0 \%$. Creatinine clearance $101 \mathrm{ml} / \mathrm{min}$. Blood urea $26 \mathrm{mg} / 100 \mathrm{ml}$, sodium $143 \mathrm{mEq} / 1$, potassium $3.8 \mathrm{mEq} / \mathrm{l}$. Blood glucose $73 \mathrm{mg} / 100 \mathrm{ml} . \mathrm{T}_{3}$ resin $44 \%, \mathrm{~T}_{4} 6.3 \mu \mathrm{g} / 100 \mathrm{ml}$, TSH $3.0 \mu \mathrm{U} / \mathrm{ml}$.

$\mathrm{X}$-ray of skull and tomography of pituitary fossanormal. X-ray abdomen and IVP demonstrated punctate calcification in the left adrenal (Fig. 1) and a normal upper urinary tract. Adrenal venography confirmed the presence of a mass approximately 2.5 $\mathrm{cm}$ in diameter in the left adrenal (Fig. 2) and a normal venous pattern on the right. 


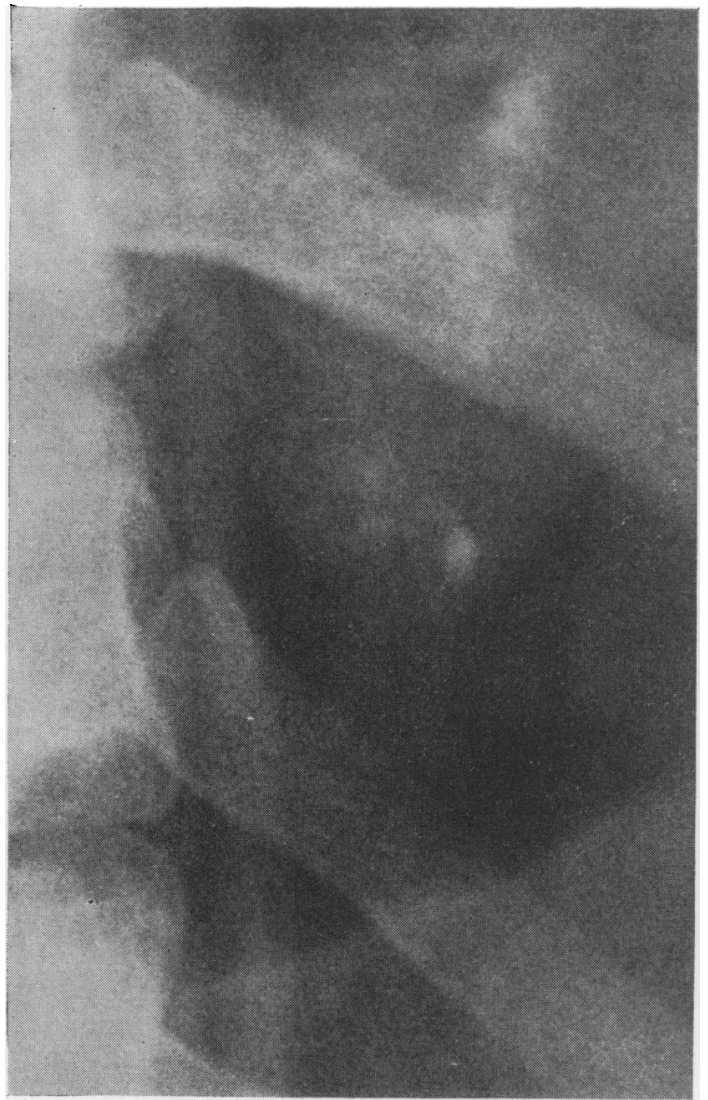

FIG. 1. Plain radiograph of left adrenal showing punctate calcification.

The effect of adrenal suppression and stimulation tests are shown on Table 1.

It can be seen from these results that the patient had relatively normal levels of plasma cortisol but there was a loss of diurnal variation. Following the administration of dexamethasone, $8 \mathrm{mg}$ daily, a striking rise occurred in both urinary and plasma steroids and during this time the patient became markedly more Cushingoid and developed ankle oedema. Further rise did not occur when the dexamethasone was increased to $16 \mathrm{mg}$ daily but no suppression was seen during this time. There was no response to lysine vasopressin but a marked rise occurred in plasma cortisol following synthetic ACTH stimulation.

In view of the radiological findings it was felt that the patient had an adrenocortical tumour and she was therefore referred for surgery. At operation the left adrenal gland was occupied by a bright yellow tumour $2.7 \times 3 \times 2 \mathrm{~cm}$ in size which was removed along with the remainder of the left adrenal. The

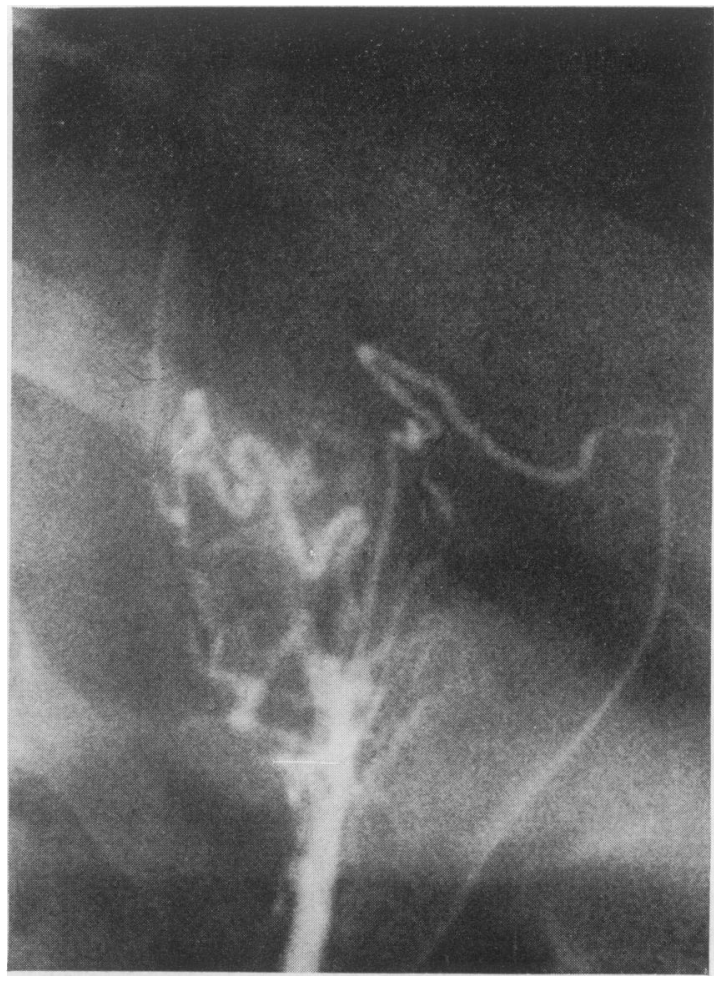

FIG. 2. Selective left adrenal venogram demonstrating the tumour in the upper pole of the adrenal.

right adrenal gland was not visualized. Histology showed an adrenocortical tumour with areas of necrosis and calcification. The nuclei of the cells were mainly uniform but a few hyperchromatic cells were present. No mitotic figures were seen. Tumour cells were seen within the capsule but there was no evidence of invasion of blood vessels. It was concluded that this was probably an adenoma although certain features suspicious of malignancy were present.

The patient had an uneventful post-operative course. The results of adrenal function tests 2 weeks after the operation are shown in Table 2.

\section{Discussion}

This patient demonstrated several features not usually encountered in Cushing's Syndrome due to an adrenal adenoma.

The first was a paradoxical rise in both plasma and urinary steroids following dexamethasone. This has been reported in both adrenal hyperplasia (Brookes et al., 1966; James, Landon \& Wynn 1965; Hardon \& Forrest, 1964) and adenoma (James et al., 1965; Liddle, 1960; Ross, Marshall-Jones \& Friedman, 1966). 
TABle 1. Pre-operation

\begin{tabular}{|c|c|c|c|c|}
\hline \multicolumn{2}{|c|}{$\begin{array}{l}\text { Plasma cortisol } \\
(\mu \mathrm{g} / 100 \mathrm{ml})\end{array}$} & \multicolumn{2}{|c|}{$\begin{array}{l}\text { Urinary steroids } \\
(\mathrm{mg} / 24 \mathrm{hr})\end{array}$} & \multirow[t]{2}{*}{ Dexamethasone } \\
\hline 9.00 & 24.00 & 17 Oxo- & 17 Oxogenic & \\
\hline 19 & 12 & $4 \cdot 2$ & 23.0 & \\
\hline 24 & 15 & - & 一 & $2 \mathrm{mg}$ at 24.00 \\
\hline 19 & - & - & $-\}$ & $0.5 \mathrm{mg} 6$ hourly \\
\hline - & 13 & $6 \cdot 0$ & $28\}$ & $0.5 \mathrm{mg} 6$ hourly \\
\hline 40 & - & - & -\{ & $2 \mathrm{mg} 6$ hourly \\
\hline 39 & 37 & $8 \cdot 6$ & $38\}$ & $2 \mathrm{mg} 6$ hourly \\
\hline - & 一 & - & $-\}$ & $4 \mathrm{mg} 6$ hourly \\
\hline 26 & 20 & $7 \cdot 0$ & $-\}$ & $4 \mathrm{mg} 6$ hourly \\
\hline \multicolumn{3}{|c|}{$\begin{array}{c}\text { Tetracosactrin test } \\
\text { (plasma cortisol } \mu \mathrm{g} / 100 \mathrm{ml} \text { ) }\end{array}$} & \multicolumn{2}{|c|}{$\begin{array}{c}\text { Lysine vasopressin test } \\
\text { (plasma cortisol } \mu \mathrm{g} / 100 \mathrm{ml} \text { ) }\end{array}$} \\
\hline \multirow{2}{*}{\multicolumn{3}{|c|}{$0.25 \mathrm{mg}$ tetracosactrin given i.m. }} & 0 min & 25 \\
\hline & & & \multicolumn{2}{|c|}{10 PU lysine vasopressin given i.m. } \\
\hline $30 \mathrm{~min}$ & 41 & & $30 \mathrm{~min}$ & 26 \\
\hline $60 \mathrm{~min}$ & 47 & & $60 \mathrm{~min}$ & 28 \\
\hline \multicolumn{5}{|c|}{ Blood from left adrenal vein-plasma cortisol $336 \mu \mathrm{g} / 100 \mathrm{ml}$. } \\
\hline
\end{tabular}

TABle 2. Post-operation

\begin{tabular}{lcc}
\hline & \multicolumn{2}{c}{$\begin{array}{c}\text { Urinary steroids } \\
(\mathrm{mg} / 24 \mathrm{hr})\end{array}$} \\
\cline { 2 - 3 } & 17 Oxo- & 17 Oxogenic \\
\hline Dexamethasone $0.5 \mathrm{mg}$ b.d. & 2.3 & 0.9 \\
Dexamethasone $0.5 \mathrm{mg}$ b.d. & 1.9 & 0.2 \\
\hline Tetracosactrin test (while on dexamethasone $0.5 \mathrm{mg} \mathrm{b} . \mathrm{d})$. \\
\multicolumn{3}{c}{ (plasma coritsol $\mu \mathrm{g} / 100 \mathrm{ml})$} \\
\hline & 1 \\
$0 \mathrm{~min}$ & \\
$1.0 \mathrm{mg}$ depot tetracosactrin given i.m. & 2 \\
$30 \mathrm{~min}$ & 3 \\
$60 \mathrm{hr}$ & 3 \\
$24 \mathrm{hr}$ & 3 \\
$30 \mathrm{hr}$ & 3 \\
\hline
\end{tabular}

The reasons for this increase are not clear, but have been attributed to direct stimulation of the adrenals by administered steroid, an alteration in extra-adrenal steroid metabolism or a positive feed-back effect on ACTH caused by dexamethasone (French et al., 1969).

Adrenal tumours are typically ACTH unresponsive although responsive adenomata have been described (Martin \& Hamman, 1966; Ross et al., 1966). James \& Landon (1968), however, suggested that there was no reason why the contralateral adrenal gland should not respond to ACTH if it had not been fully suppressed. In this case, however, the response to synthetic ACTH seen before operation (Table 1) was absent post-operatively (Table 2), showing that the ACTH responsive tissue was situated either in the tumour itself or in the uninvolved portion of the left adrenal gland.
The failure of the plasma cortisol to increase following lysine vasopressin (Table 1) is in keeping with the assertion that this response is absent in an adenoma, but present in bilateral hyperplasia (Bethge et al., 1971). However, recent reports of lysine vasopressin responsive adenomata (Demura et al. 1972) indicate that this test cannot be relied on to distinguish tumour from hyperplasia.

Another striking feature was that of radiologically evident calcification in the left adrenal (Fig. 1). Although such calcification is present in $31 \%$ of adrenal carcinomas, in a recent review Vermess, Schour \& Jaffe (1972) were only able to find two other cases of calcification in an adenoma apart from their own. Venograms revealed disordered vasculature in the region of the left adrenal but this was of little help in distinguishing between adenoma and carcinoma, although it excluded hyperplasia.

Histologically, the tumour was thought to be benign although capsular invasion was present. Clinically, the lack of virilization, the normal electrolytes, relatively low levels of plasma cortisol and urinary ketosteroids would favour an adenoma.

It is not clear why the patient developed ankle oedema only at the time of the paradoxical rise in plasma cortisol during the dexamethasone suppression test. This may have been related to the release of mineralocorticoids, but even excess cortisol per se can be responsible for sodium retention in man (Dingman et al., 1958). The oedema was self-limiting and disappeared shortly thereafter.

The increasing number of anomalous responses to both stimulation and suppression tests in the various types of Cushing's syndrome would seem to indicate that while dexamethasone suppression is still useful in making the initial diagnosis, measurement of 
plasma ACTH together with radiological visualization of the adrenal glands will have to be relied upon to place the lesion primarily in the hypothalamic-pituitary axis or in the adrenal.

\section{Acknowledgments}

We would like to thank Dr A. Swanepoel for referring the patient, Professor J. H. Louw who performed the operation and the Department of Chemical Pathology, University of Cape Town, for the steroid estimations.

\section{References}

Bethge, H., Winkelmann, W., Heesen, D., Mies, R., WeigelmanN, W. \& BAYER, J.M. (1971) Differential diagnosis of Cushing's syndrome by means of lysine vasopressin. Acta endocrinologica, Suppl. 152, 91.

Brookes, R.V., Jeffcoate, S.L., London, D.R., Prunty, F. T. G. \& SMITH, P. M. (1966) Intermittent Cushing's Syndrome with anomalous response to dexamethasone. Journal of Endocrinology, 36, 53.

Demura, R., Demura, H., Nunokawa, T., Baba, H. \& MurA, K. (1972) Response of plasma ACTH, GH and LH and $n$-hydrocorticosteroids to various stimuli in patients with Cushing's syndrome. Journal of Clinical Endocrinology, 34, 852.

Dingman, J.F., Finkenstaedt, J.T., LAIDlaw, J.C., Renold, A.E., Jenkins, J., Merril, J.P. \& Thorn, G.W. (1958) Influence of intravenously administered adrenal steroids on sodium and water excretion in normal and Addisonian subjects. Metabolism, 7, 608.

Drekter, I.J., Heisler, A., Scism, G.R., Stern, S., Pear-
SON, S. \& McGavacK, T.D. (1952) The determination of urinary steroids. Journal of Clinical Endocrinology, 12, 55.

FEw, J.D. (1961) A method for the analysis of urinary 17hydroxycorticosteroids. Journal of Endocrinology, 22, 31.

French, F.S., JefFreys, A.M., BaGget, B., Williams, T.F. \& VAN WYK, J.J. (1969) Cushing's syndrome with a paradoxical response to dexamethasone. American Journal of Medicine, 47, 619.

HARden, R. McG. \& Forrest, A.P.M. (1964) Cushing's syndrome with atypical biochemical results. Acta endocrinologica, 46, 256.

JAMES, V.H.T., LANDON, J. \& WYNN, V. (1965) Oral and intravenous suppression tests in the diagnosis of Cushing's syndrome. Journal of Endocrinology, 33, 515.

JAMES, V.H.T. \& LANDON, J. (1968) In: Recent Advances in Endocrinology, 8th edn, p. 65. Churchill, London.

LIDDLE, G.W. (1960) Tests of pituitary-adrenal suppressability in the diagnosis of Cushing's syndrome. Journal of Clinical Endocrinology, 20, 1539.

Martin, M.M. \& Hamman, B.L. (1966) Patterns of urinary excretion of steroids in Cushing's syndrome. Journal of Clinical Endocrinology, 26, 257.

Mattingly, D. (1962) A single fluorimetric method for the estimation of free 11-hydroxycorticoids in human plasma. Journal of Clinical Pathology, 15, 374.

Ross, E.J., Marshall-Jones, P. \& Friedman, M. (1966) Cushing's syndrome: diagnostic criteria. Quarterly Journal of Medicine, 35, 149.

Vermess, M., Schour, L. \& JAfFe, E.S. (1972) Calcification in benign non-functioning adrenal adenoma. Report of a case with selective adrenal arteriogram. British Journal of Radiology, 45, 621.

\title{
Acute renal failure complicating McArdle's syndrome
}

\author{
P. M. FORD \\ M.B., M.R.C.P.
}

\author{
W. R. C. WEIR \\ M.B., Ch.B.
}

\author{
A. A. H. Manugian \\ M.B., Ch.B.
}

Dundee Royal Infimary, Dundee, DD1 9ND

\section{Summary}

A case of McArdle's syndrome is described in which an epileptiform seizure was followed by acute reversible renal failure with hypercalcaemia in the diuretic phase.

\section{Introduction}

McArdle's syndrome is a rare disorder of muscle metabolism which presents in early life with pains and stiffness in the muscles during exercise. The disorder is known to be due to muscle phosphorylase deficiency (Schmid \& Mahler, 1959) and behaves as an autosomal recessive. Myoglobinuria is known to occur during attacks, but acute oliguric renal failure has been reported in only two patients (Grünfeld et al., 1972). We report a further case of renal failure associated with McArdle's syndrome with the added complication of hypercalcaemia occurring during the diuretic phase.

\section{Case report}

The patient, R.G., previously reported in a family study of McArdle's syndrome (Salter, 